\title{
Thorstein Veblen and Darwinism
}

\author{
Geoffrey M. Hodgson
}

31 December 2003

Published in the International Review of Sociology, 2004, 14(3), pp. 343-361

\author{
The Business School, University of Hertfordshire, De Havilland Campus, Hatfield, Hertfordshire AL10 9AB, UK \\ http://www.herts.ac.uk/business http://www.geoffrey-hodgson.ws \\ Address for correspondence: \\ Malting House, 1 Burton End, West Wickham, Cambridgeshire CB1 6SD, UK \\ g.m.hodgson@herts.ac.uk
}

KEY WORDS: Veblen, Darwinism, evolution, causality, variation, selection

\begin{abstract}
The aim of this article is to show how Thorstein Veblen understood and applied Darwinian principles to his analysis of the evolution of socio-economic institutions. At the core of Darwinism is a commitment to causal explanation, which Veblen adopted while not undermining his appreciation of the distinctively purposeful nature of human action. In addition, Veblen knowingly applied the Darwinian principles of variation, inheritance and selection to institutional evolution. However, despite his achievement, he did not develop an adequate or systematic theory in this area. Nevertheless, he provided a foundation upon which modern Darwinian theories of socio-economic evolution can build.
\end{abstract}




\title{
Thorstein Veblen and Darwinism
}

\author{
Geoffrey M. Hodgson ${ }^{1}$
}

Thorstein Veblen repeatedly proclaimed the need for a 'post-Darwinian' economics and saw his own work as a contribution to this endeavour. Remarkably, however, the Darwinian aspect of Veblenian thinking was largely neglected, both by later commentators and by the tradition of American institutionalism that Veblen inspired (Hodgson, 2003, 2004). Veblen was widely admired, but his frequent Darwinian injunctions were rarely followed in detail. The aim of the present paper is to explore the manner and extent of Veblen's use of Darwinian ideas in his evolutionary and institutional economics.

This paper is organized in six sections. The first section outlines the fundamental features of Darwinism that are relevant for social as well as biological evolution. The second section discusses how Veblen replicated and adopted Darwinian notions of causality in his writing. The third section deals with some misunderstandings concerning Veblen's treatment of the concept of intentionality, and its relation to his Darwinism. The fourth and fifth sections address Veblen's application of the Darwinian principles of variation, inheritance and selection to the evolution of institutions. The final section concludes the essay, by assessing Veblen's omissions and achievements in this area.

\section{What is Darwinism?}

A host of misunderstandings surround the question of Darwinism and its relation with the social sciences. Contrary to widespread suppositions, Darwinism neither connotes any form of racism, sexism, nationalism or imperialism nor does it provide any moral justification for 'the survival of the fittest'. Furthermore, Darwinism does not imply that militant conflict is inevitable, that human inequalities or power or wealth are inevitable, that cooperation or altruism are unimportant or unnatural, that evolution always leads to optimization or progress, that social phenomena can or should be explained in terms of biology alone, that organisms can or should be explained in terms of their genes alone, that human intention is unimportant, or that human agency is blind or mechanistic.

Humans differ from plants and most animals, in that they have language and culture. We prefigure many actions and consequences in our minds, and act intentionally. The mechanisms of human socio-economic evolution and biotic evolution are very different. In studying socio-economic evolution we are concerned with human welfare and well-being, and not merely with survival or fecundity. All that is vitally important. But it does not diminish the importance or analytical value of Darwinism one iota.

\footnotetext{
1 This paper makes use of material from Hodgson (2003, 2004). The author thanks participants at the November 2003 Bevagna seminar for comments and discussions.
} 
Above all, Darwinism means causal explanation, where a cause is understood as necessarily involving transfers of matter or energy. Divine, spiritual, miraculous or uncaused causes are ruled out. Explanations of outcomes are in terms of connected causal sequences, based on the presupposition that every event or phenomenon has a cause. As the institutional economist Albert Wolfe (1924, p. 465) put it: 'All science must ... rest on the faith that nothing happens without a cause and that every cause has an effect.' This applies to human intentionality as well as everything else. Contrary to widespread belief, causal explanation does not mean that intentions are ignored in Darwinism; it simply means that they are caused, and they have to be explained. Also contrary to common belief, the commitment to the idea that every event or phenomenon has a cause does not imply that every event is predictable, or event regularities are pervasive, or that the universe is a Parmenidean block or a machine. The principle of causal determination is not the same as determinism, as it is often defined (Bunge, 1959; Hodgson, 2001b, 2004).

Charles Darwin died decades before the idea of a gene was formulated and before the incorporation of Mendelian genetics into biology. Without relevant knowledge of the mechanisms of reproduction, Darwin did not rule out the possibility of the Lamarckian inheritance of acquired characters.

The importance and enduring value of Darwinism is its elaboration of a causal mechanism of evolution involving variation, inheritance and selection. In principle, this mechanism could apply to any open and evolving system with a variety of units. Darwinian evolution occurs when there is some replicating entity that makes imperfect copies of itself, and these copies do not have equal potential to survive.

Darwin (1859, 422-3; 1871, vol. 1, 59-61) himself conjectured that natural selection operates upon the elements of human language as well as on individual organisms. Darwin (1871, vol. 1, 166) also argued that tribal groups with propensities that served the common good would be favored by "natural selection". Hence Darwin seemed to endorse a version of the natural selection of groups, as well as the natural selection of individuals. Several modern Darwinian biologists have argued that evolutionary selection occurs at higher levels: not simply on genes, but on individuals, groups and even species. ${ }^{2}$

The core ideas of Darwinism were not widely understood in the decades after 1859 (Bowler, 1988) and they are still misunderstood by many today. Darwin was more widely associated with the proposition that humankind is descended from apes, rather than with his particular causal evolutionary mechanism.

Nevertheless, a small number of astute thinkers followed Darwin; to consider the possibility that Darwinian mechanisms - in the general sense described above - might also apply to the evolution of societies, cultures and ideas. Walter Bagehot (1872) wrote of inheritance and natural selection in the social and political sphere. William James (1880, p. 441) opened a path-breaking essay with the observation of a "remarkable parallel ... between the facts of social evolution on the one hand, and of zoölogical evolution as expounded by Mr. Darwin on the other." Subsequently Samuel Alexander (1892) and Benjamin Kidd (1894) wrote on the natural selection of ethical principles. Finally, and in the most sophisticated presentation so far, David Ritchie (1896, p. 171) considered “a 'natural selection' of ideas, customs,

\footnotetext{
2 See, for example, Brandon and Burian (1984), Eldredge (1985), and Sober and Wilson (1998).
} 
institutions, irrespective of the natural selection of individuals and of races." The scene was set for Veblen's crucial innovations. ${ }^{3}$

\section{Veblen's Darwinian Emphasis on Causation}

This section summarizes the way in which Veblen applied Darwinian ideas to economics. First, Veblen understood and endorsed the principles of causality that were fundamental to Darwinism. For Veblen, the Darwinian rejection of teleology became the necessary basis of a scientific and 'post-Darwinian' approach to economics and social science. There is abundant evidence that Veblen understood Darwinism most fundamentally in terms of a commitment to detailed and sequential causal analysis. For example, Veblen (1898a, pp. 375-8) wrote:

Any evolutionary science ... is a close-knit body of theory. It is a theory of a process, of an unfolding sequence ... of cumulative causation. The great deserts of the evolutionist leaders ... lie ... in their having shown how this colorless impersonal sequence of cause and effect can be made use of for theory proper, by virtue of its cumulative character.

This insistence on explanation in terms of a cumulative causal sequence was repeated in several works (Veblen, 1898a, pp. 381, 384, 386; 1900, p. 266; 1904, pp. 67, 313, 314, 365). Although Darwin himself did not use the term 'cumulative causation', it is important to underline the way that Veblen (1904, p. 370) saw it as linked with Darwinism:

His [Darwin's] inquiry characteristically confines itself to the process of cumulative change. His results, as well as his specific determination of the factors at work in this process of cumulative change, have been questioned; perhaps they are open to all the criticisms levelled against them as well as a few more not thought of; but the scope and method given to scientific enquiry by Darwin and the generation whose spokesman he is has substantially not been questioned, except by that diminishing contingent of the faithful ...

Veblen (1907, p. 304) also wrote that

in the Darwinian scheme of thought, the continuity sought in and imputed to the facts is a continuity of cause and effect. It is a scheme of blindly cumulative causation, in which there is no trend, no final term, no consummation. The sequence is controlled by nothing but the vis a tergo of brute causation, and is essentially mechanical.

The ambiguous words 'blindly' and 'mechanical' in the above quotation might cause some confusion. There is no warrant for assuming that for Veblen they meant a lack of individual purpose or will, but they could encourage such a misinterpretation. Veblen must be criticized for using such terms, at least in an unqualified manner. Nevertheless, his key point of emphasis was one of causal sequence. Veblen (1919, p. 37) visited this theme persistently, as in these words originally published in 1908:

The characteristic feature by which post-Darwinian science is contrasted with what went before is a new distribution of emphasis, whereby the process of causation, the interval of

\footnotetext{
3 The idea of extending the range of Darwinian principles outside the biological sphere was later described by Dawkins (1983) and Dennett (1995) as 'Universal Darwinism'. Previously, Campbell (1965) had also developed the idea of a generalized Darwinism. Note, however, that the Dawkins-Dennett version sees the social unit of selection as the 'meme', while Veblen in contrast emphasized the selection of individual habits and social institutions.
} 
instability and transition between initial cause and definitive effect, has come to take the first place in the inquiry; instead of that consummation in which causal effect was once presumed to come to rest. This change in point of view was, of course, not abrupt or catastrophic. But it has latterly gone so far that modern science is becoming substantially a theory of the process of consecutive change, realized to be self-continuing or selfpropagating and to have no final term.

In the same year Veblen $(1908$, p. 159 n.) wrote of 'the field of cumulative change within which the modern post-Darwinian sciences live and move and have their being.' A few commentators on Veblen have recognized this crucial Darwinian focus on causal processes in Veblen's writings. As Karl Anderson (1933, p. 602) put it, modern science for Veblen 'demands an explanation of things in terms of cause and effect, and postulates that the causal relationship has neither starting-point nor stopping-point but runs in an endless sequence.' Similarly, Idus Murphree (1959, p. 312) remarked that Veblen 'thought of the Darwinian method as one that revealed the impersonal sequence of mechanical cause and effect and dispensed with a search for universal purposes and belief in a "natural order".'

Veblen and others sometimes described this emphasis on detailed, step-by-step causal explanation as part of the 'genetic' method. Veblen (1903, p. 655) explained the 'genetic' method of 'modern science' as applied to social phenomena:

This method is the genetic one, which deals with the forces and sequence of development and seeks to understand the outcome by finding how and why it has come about. The aim is to organize social phenomena into a theoretical structure in causal terms.

The term 'genetic' like 'genesis' refers to causal origin or determination. ${ }^{4}$ The word 'genetic' had been widely used in methodological or scientific contexts in the nineteenth century, and it should not be confused with the modern biological term 'gene'. The 'gene' concept was first introduced into biology in 1909 by Wilhelm Johannsen. It would thus be an appalling error to interpret Veblen's use of the term 'genetic' as an accommodation to genetic reductionism!

In Veblen's writing there was the same emphasis on the detailed and processual nature of Darwinian evolution as in the modern work of Daniel Dennett (1995). Although Veblen did not use the word, he had as much appreciation as Dennett of the nature of Darwinian evolution as an 'algorithmic' process. Veblen used phrases such as 'genetic theory', 'cumulative causation', 'theory of a process, of an unfolding sequence' and 'impersonal sequence of cause and effect' to connote the same idea. This Darwinian focus on algorithmic processes is both revolutionary and highly modern; it directs attention to ongoing processes rather than static equilibria alone. ${ }^{5}$

\footnotetext{
4 The German term genetisch also alludes to origins and is found in the in the eighteenth-century writings of Herder and Schiller. Apparently, the word 'genetic' in this same general (and not particularly biological) sense was introduced into English by Carlyle (Hayek, 1988, p. 147).

5 However, the differences between Dennett and Veblen should not be overlooked. For example, Dennett's (1995) devotion to the vague concept of the 'meme' as the unit of cultural evolution contrasts with Veblen's pragmatist insistence on habit as the basis of ideas and essence of culture and his emphasis on emergent institutions as units of selection. One of the problems with 'memetics' is that the causes of meme replication are unexplained, while Veblen explained the replication of institutions in terms of the psychological mechanisms of individual habit formation. Furthermore, Veblen's (1909a, p. 300) strictures against reductionism have no adequate parallel in Dennett (1995).
} 
However, while Veblen coined the term 'cumulative' causation, he used it primarily to refer to cumulative sequences of cause and effect. ${ }^{6}$ With other authors, the term 'cumulative causation' took on the different meaning (in modern parlance) of non-linear processes of positive feedback. For instance, in his classic article on 'increasing returns' Allyn Young (1928, p. 533) wrote that: 'change becomes progressive and propagates itself in a cumulative way'. One of his students was Nicholas Kaldor (1985), who made extensive use of Young's positive-feedback notion of 'cumulative causation'. Gunnar Myrdal (1939, 1957) independently took the idea of cumulative causation from the positive feedback mechanisms in the monetary economics of fellow Swedish economist Knut Wicksell.

Veblen used the idea of an unbroken historical chain of cause and effect to undermine the presuppositions of mainstream economics. His use of Darwinian methodological injunctions led to a powerful critique. Ultimately, because the human agent was a subject of an evolutionary process, he or she could not be taken as fixed or given. A causal account of the interaction between the individual and social structure had to be provided. This causal account should not stop with the individual, but it should also attempt to explain the origin of psychological purposes and preferences.

Veblen argued that a problem with mainstream economics was that it provided a causal and evolutionary explanation neither of 'rational economic man' nor of his given preference function (Argyrous and Sethi, 1996; Hodgson, 1998). How did such rationality and preferences appear in human evolution? What causes and processes brought them into being? How and when are they formed in the development of each human individual? For Veblen, such an escape from evolutionary principles was impossible. Darwinism meant not only a critique of Divine intervention, but it also required a rejection of immanently conceived preference functions. As a result, the universal assumption in neoclassical economics 'of a passive and substantially inert and immutably given human nature' (Veblen, 1898b, p. 389) had to be criticized.

Veblen upheld that utilitarian and hedonistic explanations of human behaviour were inadequate because they did not encompass an evolutionary and causal explanation of the origin of the assumed behavioural characteristics. The neoclassical assumption of given preferences side-steps an explanation of the origin and initial acquisition of those preferences. The assumption that individuals are selfish requires an explanation of the evolution of selfishness. In general, postulates about human behaviour at the socio-economic level themselves require explanation in evolutionary terms.

\section{Veblen on Intentionality and Causality}

Veblen attempted to reconcile the reality of human will and intentionality with science and causal explanations. In his first published article of 1884, Veblen (1934, p. 175) noted the contradiction between 'freedom of the person' in Kant's Critique of Practical Reason and 'the notion of strict determinism' found in his Critique of Pure Reason. Veblen saw in Kant the idea that 'in order to free activity, a mediation between the two was likewise indispensable.' Veblen's subsequent writing also involved an attempt to mediate between 'freedom' and 'determinism', but one that was consistent with Darwinian principles. Veblen neither denied nor underestimated the significance of human intentionality, but saw it as a result of

\footnotetext{
6 A possible exception is where Veblen (1904, p. 368) wrote of 'complex' processes 'in which any appreciable deviation may forthwith count in a cumulative manner'.
} 
evolution. Darwin rejected religious and teleological explanations of origin or destiny. Veblen rejected them too, while attempting to leave an intermediate place for 'teleology' in human purposeful behaviour. He retained the idea that persons were purposeful, but Veblen (1898c, pp. 188-93) placed this proposition within an evolutionary framework:

Like other animals, man is an agent that acts in response to stimuli afforded by the environment in which he lives. Like other species, he is a creature of habit and propensity. But in a higher degree than other species, man mentally digests the content of habits under whose guidance he acts, and appreciates the trend of these habits and propensities. ... By selective necessity he is endowed with a proclivity for purposeful action. ... He acts under the guidance of propensities which have been imposed upon him by the process of selection to which he owes his differentiation from other species.

Hence Veblen followed Darwin and regarded human intentionality as a capacity that had itself evolved through natural selection. As Veblen (1899a, p. 15) put it in another work, the capacity of humankind to act with deliberation towards ends was itself a result of natural selection:

As a matter of selective necessity, man is an agent. He is, in his own apprehension, a centre of unfolding impulsive activity - 'teleological' activity. He is an agent seeking in every act the accomplishment of some concrete, objective, impersonal end.

Despite this, Veblen is widely misunderstood as underestimating the actuality or significance of human intentionality and purposefulness. On the contrary, Veblen (1898b, p. 391) insisted: 'Economic action is teleological, in the sense that men always and everywhere seek to do something.' The fact that such purposeful behaviour itself emerged through evolutionary selection does not mean a denial of the reality of purposeful behaviour. Instead, Veblen consistently tried to reconcile a notion of individual purposefulness (or sufficient reason) with his materialist idea of causality (or efficient cause).

Intentions can themselves be causes, but intentions are always caused. The evolution of human intentionality, and its development within each human being, has to be explained in terms of materialist causes and evolutionary selection. As noted above, this is an aspect of the Darwinian commitment to causal explanation. Like Darwin, T. H. Huxley, G. H. Lewes and C. L. Morgan, Veblen rejected a dualist or Cartesian ontology that separated intentionality completely from matter and materialist causality. Veblen (1909b, pp. 624-5) saw such a dualism as unacceptable for the following reason:

The two methods of inference - from sufficient reason [or intention] and from efficient [or materialist] cause - are out of touch with one another and there is no transition from one to the other: no method of converting the procedure or the results of the one into those of the other.

Others since have echoed Veblen's argument against the idea of separate types of cause, and against the related Cartesian dualism of matter and mind. For example, Barry Hindess (1989, p. 150) asked pertinently: 'If human action is subject to two distinct modes of determination, what happens when they conflict, when intentionality pushes one way and causality pushes another?' We do not and cannot know the answer, because to reach it would involve the reconciliation of irreconcilables. John Searle (1997, pp. xii-xiii) similarly remarked: 'dualism ... seems a hopeless theory because, having made a strict distinction between the mental and the physical, it cannot make the relation of the two intelligible.' Mario Bunge (1980, p. 20) put it in a nutshell: 'Dualism is inconsistent with the ontology of science.' 
Veblen perceived the consequences for the social sciences of this mistaken dualism. For example: "The immediate consequence is that the resulting economic theory is of a teleological character - "deductive" or "a priori" as it is often called - instead of being drawn in terms of cause and effect' (Veblen, 1909b, p. 625). His solution, following Darwin, was to place human intentionality in an evolutionary context. At least in principle, consciousness had to be explained in Darwinian and evolutionary terms. As Veblen (1906, p. 589) alluded: 'While knowledge is construed in teleological terms, in terms of personal interest and attention, this teleological aptitude is itself reducible to a product of unteleological natural selection.' In the following passage, Veblen (1909b, p. 625) explained in more detail:

The modern scheme of knowledge, on the whole, rests, for its definitive ground, on the relation of cause and effect; the relation of sufficient reason [or intention] being admitted only provisionally and as a proximate factor in that analysis, always with the unambiguous reservation that the analysis must ultimately come to rest in terms of cause and effect.

But this does mean that intentionality (or sufficient reason) is nonexistent or unimportant. On the contrary, Veblen $(1909 \mathrm{~b}$, p. 625) acknowledged 'that the relation of sufficient reason enters very substantially into human conduct. It is this element of discriminating forethought that distinguishes human conduct from brute behavior.' Veblen (1909b, p. 626) then went on to observe and approve that 'modern science at large has made the causal relation the sole ultimate ground of theoretical formulation'. Veblen saw 'the relation of sufficient reason as a proximate, supplementary, or intermediate ground, subsidiary, and subservient to the argument from cause to effect.'

In sum, while human intentionality is real and consequential, and a necessary element in any causal explanation in the social sciences, intentions themselves had at some time to be explained. As Veblen (1909b, p. 626) put it, explanation could not be confined to the 'rationalistic, teleological terms of calculation and choice' because the psychological beliefs and mechanisms that lay behind deliberation and preferences had also to be explained in terms of a 'sequence of cause and effect, by force of such elements as habituation and conventional requirements.' By acknowledging the need for such causal explanations, Veblen rejected both the assumption of the given individual in neoclassical economics and the opposite error of regarding human agency as entirely an outcome of mysterious social forces.

As well as to Darwin, Veblen's treatment of intentionality owed a great deal to the then emerging tradition of American pragmatism. Hans Joas (1996, p. 158) succinctly summarized the pragmatist contribution in this area:

The alternative to a teleological interpretation of action, with its inherent dependence on Cartesian dualisms, is to conceive of perception and cognition not as preceding action but rather as a phase of action by which action is directed and redirected in its situational contexts. According to this alternative view, goal-setting does not take place by an act of intellect prior to the actual action, but is instead the result of a reflection on aspirations and tendencies that are pre-reflexive and have already always been operative. In this act of reflection, we thematize aspirations which are normally at work without our being actively aware of them. But where exactly are these aspirations located? They are located in our bodies. It is the body's capabilities, habits and ways of relating to its environment which form the background to all conscious goal-setting, in other words, to our intentionality. Intentionality itself, then, consists in a self-reflective control which we exercise over our current behavior. 
Although Veblen rarely spelt out such matters in sufficient detail, I submit that this pragmatist conception of action is entirely consistent with his own expressed views, and its adoption is explicable in terms of his knowledge of the ideas of Charles Sanders Peirce, William James and John Dewey. In this pragmatist view, intentionality is not denied but placed in the context of habits of thought and behaviour.

Veblen's position on intentionality has been the subject of some misunderstanding. John R. Commons (1924, p. 376) referred to the natural selection stage of blind evolution that followed Darwin, whose distinguished exponent in economics is Veblen. The theorists of each stage attempted to get rid of the human will and to explain economic phenomena as the working out of natural forces.' This assessment replicates the misunderstanding that Darwinism necessarily excludes intentionality or will.

David Seckler (1975, p. 56) came to the verdict that Veblen 'teeters between free will and determinism'. But Seckler did not define these terms adequately. Sure enough, Veblen can be criticized for sometimes describing a Darwinian causal process as 'mechanical'. This can give the impression that intentionality or purposefulness is excluded. But Veblen acknowledged the reality of purposeful behaviour. While Seckler $(1975$, p. 86) accepted the 'methodological dualism' of Ludwig von Mises (1949) and others, Veblen (1898b, p. 386) argued in contrast that the dualist position of the Austrian school should be dissolved by bringing purposes and preferences within the orbit of scientific explanation. What Seckler failed to understand was that Veblen was trying to overcome the problems of dualism. Veblen was not trying to dispense with human will but to reconcile it with materialist causality. Admittedly, Veblen was not entirely successful in formulating this position. But Veblen's shortcomings are no excuse for ignoring his efforts in that direction.

Richard Langlois (1986, p. 4) alleged that Veblen 'wished to rid economics of any sort of human intelligence and purpose.' Similarly, in an incisive essay on Veblen, Malcolm Rutherford (1998, pp. 475-6) saw problems emanating from Veblen's non-teleological notion of explanation in the social sciences:

Following Darwin, [Veblen] sought an evolutionary theory that was free from teleology and ran in purely causal terms. He was aware that individuals acted in a goal-directed manner, but he wanted to present institutional change as unintended result - as a result of a causal process that did not rely on intentionality or on the appraisal of one institutional scheme as compared to another.

Rutherford is one of the best interpreters of Veblen, and Langlois is an incisive theorist. But both writers distort Veblen's position here. Neither Veblen nor Darwin dismissed intentionality, but saw teleological or goal-directed behaviour as explicable in causal terms. Contrary to Rutherford, Veblen's explanation of action and institutional change did involve intentionality. It should be clear from the quotations above that Veblen saw intentionality as part of the explanation of institutional change. Veblen recognized purposeful behaviour but saw it as ultimately explicable in causal terms.

Veblen outlined the problem of reconciling human volition and causality but failed to develop an adequate and non-reductionist philosophical framework in which human intentionality, monism and causality could be reconciled; without reducing mind to matter, or matter to mind. In retrospect, a missing conceptual tool was an explicit and developed concept of emergence in the context of a layered ontology. Modern philosophers make much use of these concepts in their treatment of the mind-body problem (Bunge, 1980; Sperry, 1991). However, emergentist philosophy did not come to maturity until the 1920s, at the very end of Veblen's life. 
The importance of choice and intentionality in human affairs does not undermine the principle of evolutionary selection. Unlike Veblen, John R. Commons insisted that Darwinism was inappropriate for the understanding of socio-economic evolution, because humans made deliberate choices concerning socio-economic possibilities. Commons (1924, p. 376) thus wrote: 'Economic phenomena ... are the result of artificial selection and not of natural selection.' Commons (1934, pp. 45, 120, 636-8, 657-8, 713) persisted in his view that economic evolution involved 'artificial selection' rather than 'natural selection.' However, Darwin did not suggest that 'artificial' and 'natural' selection were mutually exclusive. Instead, examples of the former were used to support the idea of the latter. As Darwin's friend George Romanes $(1893,296)$ wrote in explaining Darwin's theory: 'In a word, the proved capabilities of artificial selection furnish, in its best conceivable form, what is called an argument a fortiori in favour of natural selection. ${ }^{7}$

\section{Veblen's Adoption of the Darwinian Principles of Variation and Inheritance}

Despite his extensive knowledge of biology, Veblen was too careful to commit himself in the then ongoing and unresolved debate over Lamarckism. Whether acquired characters could be inherited or not was in part an empirical question, to be answered by biological research. These issues were far from resolution in the biology of the 1890s and early 1900s; too little was understood of the mechanisms of genetic inheritance. Veblen did not wish to build his theory on what might be shifting scientific sands, and he took from Charles Darwin what he rightly regarded to be most decisive and enduring: the Darwinian principle of selection and the emphasis on causation. Veblen remained neutral on the question of whether or not acquired characters could be inherited. The outcome of this controversy did not affect key parts of his argument. Veblen (1899a, pp. 190, 192) thus wrote:

For the present purpose, however, the question as to the nature of the adaptive process whether it is chiefly a selection between stable types of temperament and character, or chiefly an adaptation of men's habits of thought to changing circumstances - is of less important than the fact that, by one method or another, institutions change and develop. ... For the immediate purpose it need not be a question of serious importance whether this adaptive process is a process of selection and survival of persistent ethnic types or a process of individual adaptation and an inheritance of acquired traits.

But while Veblen (1899a, p. 248) admitted the possibility that differences 'in temperament may be due in part to a difference in the inheritance of acquired traits' he was not neutral between the theories of Darwin and Lamarck. Veblen (1904, p. 369) wrote: 'Darwin set to work to explain species in terms of the process out of which they have arisen, rather than out of the prime cause to which the distinction between them may be due.' What Darwin had tried to do, albeit without complete success, was to provide a processual explanation of the origin of species where the causal mechanisms involved were fully specified. Veblen (1904, p. 369 n.) continued in a highly perceptive footnote: 'This is the substance of Darwin's advance over Lamarck, for instance.' On this basis of more adequate causal explanations of process, Veblen rightly judged Darwin to be superior to Lamarck.

\footnotetext{
7 I have criticised Commons's rejection of Darwinism elsewhere (Hodgson, 2002, 2004). At the time, Copeland (1936, pp. 343-4) pointed out that Commons's 'artificial selection' of institutions depended on the prior 'natural selection' of the guiding ethical or other principles that were used in the selecting process. Copeland's valid point was that the evolution of the criteria used in any 'artificial' selection must also be explained. But Commons lacked even a rudimentary theory of what causes human motivation, action or choice.
} 
Veblen understood that the process of Darwinian evolution had three important aspects. First, there must be sustained variation among the members of a species or population. Variations may be random or purposive in origin, but without them, as Darwin insisted, natural selection cannot operate. This is the concept of variation. Second, there must be some mechanism of heredity or continuity, through which offspring have to resemble their parents more than they resemble other members of their species. In other words, there has to be some mechanism through which individual characteristics are passed on through the generations. Third, natural selection itself operates either because better-adapted organisms leave increased numbers of offspring, or because the variations or gene combinations that are preserved are those bestowing advantage in struggling to survive. This is the concept of the struggle for existence. Consider these three features in turn, as they appear in Veblen's work.

For Veblen (1900, p. 266) a Darwinian science must address 'the conditions of variational growth'. Veblen (1901b, p. 81) saw a 'Darwinistic account' in economics as addressing 'the origin, growth, persistence, and variation of institutions'. Veblen (1899a, p. 217) also referred to 'a selection between the predatory and the peaceable variants'. This indicated that for Veblen, and in conformity with Darwin, variation exists prior to (as well as after) evolutionary selection.

Veblen did not provide a full account of the sources of variation of social institutions. In general, Veblen (1909b, p. 628) saw cultural variation as cumulative: 'The growth of culture is a cumulative sequence of habituation' but 'each new move creates a new situation which induces a further new variation in the habitual manner of response' and 'each new situation is a variation of what has gone before and embodies as causal factors all that has been effected by what went before'.

For Veblen, the 'instinctive propensity' of 'idle curiosity' was also a major ongoing source of variety and invention. 'This instinctive curiosity' may 'accelerate the gain in technological insight' as well as 'persistently disturbing the habitual body of knowledge' (Veblen, 1914, p. 87). Note here that Veblen was again disposed to bring in an instinctive explanation of social outcomes. Especially to the modern reader, this is not so convincing. But the validity or otherwise of this point should be a matter not of prejudice against the concept of instinct but of scientific investigation. ${ }^{8}$

Veblen also used the metaphor of mutation, applying it to social and economic institutions. In 1901 the Dutch biologist Hugo De Vries published Die mutationstheorie in German. It noted the forgotten genetic discoveries of Gregor Mendel and proposed his own 'mutation theory'. The rediscovery of Mendelian genetics eventually led to the modern neo-Darwinian synthesis in biology and the victory of the Darwinians over the Lamarckians. But this did not occur until the 1940s, long after Veblen's death. In 1910 Veblen started work on a paper that explicitly incorporated some of De Vries's ideas. ${ }^{9}$

The first appearances of the use of the term 'mutation' in an institutional context in Veblen's writings are 'business capital and its mutations' (Veblen, 1904, p. 149), 'effects of these institutions and of the mutations they undergo' and 'growth and mutations of the institutional fabric' (Veblen, 1909b, pp. 627-9). Much later Veblen (1919b, pp. 5, 40) wrote

\footnotetext{
${ }^{8}$ One of the earliest references to 'idle curiosity' is in Veblen (1906, p. 590).

${ }^{9}$ Dorfman (1934, p. 295). This paper was published three years later (Veblen, 1913).
} 
of 'the mutation of habits' and proposed that 'the state of the industrial arts has been undergoing a change of type, such as followers of Mendel would call a "mutation". ${ }^{10}$

We now turn to the second Darwinian concept, the question of inheritance. It is clear from the Leisure Class that the institution was regarded as the unit of relative stability and continuity through time, ensuring that much of the pattern and variety is passed on from one period to the next. Veblen (1899a, p. 191) wrote:

Institutions are products of the past process, are adapted to past circumstances, and are therefore never in full accord with the requirements of the present. ... At the same time, men's present habits of thought tend to persist indefinitely, except as circumstances enforce a change. These institutions which have so been handed down, these habits of thought, points of view, mental attitudes and aptitudes, or what not, are therefore themselves a conservative factor. This is the factor of social inertia, psychological inertia, conservatism.

This relative stability and durability of habits and institutions made them key objects of evolutionary selection in the socio-economic sphere. But Veblen did not examine the processes or institutional replication or inheritance in sufficient detail.

\section{Veblen and Darwinian Selection}

Turning to the concept of selection, Veblen (1899a, p. 188) famously promoted the idea that in social evolution there was a 'natural selection of institutions':

The life of man in society, just like the life of other species, is a struggle for existence, and therefore it is a process of selective adaptation. The evolution of social structure has been a process of natural selection of institutions. The progress which has been and is being made in human institutions and in human character may be set down, broadly, to a natural selection of the fittest habits of thought and to a process of enforced adaptation of individuals to an environment which has progressively changed with the growth of community and with the changing institutions under which men have lived. Institutions are not only themselves the result of a selective and adaptive process which shapes the prevailing or dominant types of spiritual attitude and aptitudes; they are at the same time special methods of life and human relations, and are therefore in their turn efficient factors of selection. So that the changing institutions in their turn make for a further selection of individuals endowed with the fittest temperament, and a further adaptation of individual temperament and habits to the changing environment through the formation of new institutions.

It was no accident that Darwin's phrases 'natural selection' and 'struggle for existence' appeared here. Veblen (1899a, p. 207) wrote also in the same work of 'the law of natural selection, as applied to human institutions'. Elsewhere Veblen (1898c, p. 188; 1900, pp. 241, 261,$217 ; 1906$, p. 589) poignantly but infrequently applied the specific phrase 'natural selection' to habits of thought or to social institutions. The decisive implication was that Darwinism could be applied to human society without necessarily reducing explanations of social phenomena entirely to individual psychology or biology.

10 Veblen (1914, pp. 16-18, 21-5, 69, 140; 1915, pp. 277-8; 1925, p. 51) repeatedly referred to Mendelian genetics in his later works. 
Although Veblen used the phrase 'natural selection' only a few times, the concept of selection is common and persistent in his works. Words such as 'select', 'selection' and 'selective', used in the Darwinian sense of a process of sifting and preservation of fortuitous adaptations, are used with conspicuous frequency. I have counted well over a hundred appearances. A large number of these appearances concern the selection of institutions, customs or habits of thought. Confining ourselves to the Leisure Class (Veblen, 1899a) alone, the following examples are a small sample:

In whatever way usages and customs and methods of expenditure arise, they are all subject to the selective action of this norm of reputability; and the degree in which they conform to its requirements is a test of their fitness to survive in the competition with other similar usages and canons. (p. 166)

There is a cumulative growth of customs and habits of thought; a selective adaptation of conventions and methods of life. (p. 208)

Social evolution is a process of selective adaptation of temperament and habits of thought under the stress of the circumstances of associated life. The adaptation of habits of thought is the growth of institutions. ... a process of selection ... a selective process ... (pp. 213-4)

Wherever the pecuniary culture prevails, the selective process by which men's habits of thought are shaped, and by which the survival of rival lines of descent is decided, proceeds proximately on the basis of fitness for acquisition. (p. 241)

This and much other textual evidence on his use of the concept of selection, along with his understanding of the importance of variation and inheritance in the Darwinian theory, decisively favours an interpretation of Veblen's work as one in which Darwinian principles are applied to the analysis of social evolution.

It must again be emphasized that Veblen's Darwinian economics did not involve the assertion that economic evolution can or must be reduced substantially to biological terms. Furthermore, Veblen's use of Darwinian terminology was not confined to metaphor. Veblen made it abundantly clear that he believed that socio-economic systems actually evolved in a manner consistent with the Darwinian concepts of variation, inheritance and selection. Veblen did not believe that the application of Darwinian theory was confined to nature. In his social theory, his use of Darwinian theory was much more than mere word play. The difference between natural and social evolution was in the units of selection and in the details of the evolutionary processes, not in the exclusion of variation, inheritance or selection from the social sphere. Variation, inheritance and selection are present and real in both the social and the natural context. ${ }^{11}$

The relatively infrequent appearance of the phrase 'natural selection' does not undermine the claim that Veblen was an evolutionary economist in a Darwinian genre. As mentioned above, he used the concept of selection frequently. But it remains to consider why Veblen did not often choose to attach the adjective 'natural' to the abundant instances of 'selection' or 'selection process' in his work. We may guess why. First, and most obviously, Veblen was concerned with the evolution of society, and not of the non-human, natural world. As his attention was directed at society rather than nature, the term 'natural' was dropped. Second,

\footnotetext{
11 For discussions of the Darwinian character of Veblen's work see Harris (1934), Daugert (1950), Hill (1958), Murphree (1959), Russett (1976), Dugger, (1984), Edgell and Tilman (1989), Tilman (1992, 1996) and many others. See Jennings and Waller (1998) for a contrary but unconvincing view.
} 
the 'natural selection' of institutions could be misinterpreted by the reader in terms of 'nature' doing the selecting, or that the selection was taking place according to 'natural' rather than economic or other social criteria. Third, economists and others who advocated a 'natural' order, or 'natural rights', were the persistent objects of Veblen's $(1899 \mathrm{~b} ; 1$ 1901a; 1908; 1914, pp. 258-60, 289-98, 340-3) devastating criticism. Resistance to the likely interpretations of the word 'natural' as 'normal' or 'predestined' could have led to the rejection of the term, especially when the word 'selection' on its own would do. Hence there are several possible reasons why Veblen more frequently used the word 'selection' rather than 'natural selection'. As a result, the marginalization of the word 'natural' in his writing should not be taken to imply that Veblen lost any of his Darwinian inspiration. ${ }^{12}$

Incidentally, for different reasons, Darwin himself was uneasy about the phrase 'natural selection'. It was suggested to him that the word 'selection' invoked the image of 'nature's Guiding Hand', or even one of God being the selector. Darwin thus conceded: 'I suppose "natural selection" was a bad term' (Desmond and Moore, 1991, pp. 458, 492). For this reason Darwin sometimes used the words 'descent with modification' instead. He ultimately preferred the term 'natural preservation' (Ruse, 1979, p. 208). Both Darwin and Veblen were hesitant about the use of the term 'natural selection' but for different reasons. Darwin cultivated the word 'natural' and Veblen economized and used the word 'selection' alone.

While Veblen generally saw institutions as units of selection in a process of economic evolution, he did not make the context, criteria or mechanisms of selection entirely clear. Prompted by the notion that the social 'environment' itself evolves, Veblen (1899a, pp. 18898) moved towards, but did not complete, a causal analysis of that evolutionary process. Insofar as an evolutionary analysis exists, we have to impute it from passages such as the one quoted above, where Veblen (1899a, p. 191) wrote that the 'selective adaptation can never catch up with the progressively changing situation in which the community finds itself at any given time'. This suggests a process of imperfect institutional adjustment and cultural lag. But it does not sufficiently explain the evolution of the 'progressively changing situation' in which institutions are selected.

\section{Conclusion: Success and Failure in Veblen's Darwinism}

Nevertheless, Veblen was clearly attempting to move towards a theory of institutional evolution. In its time and context, this sketchy and preliminary analysis of institutional evolution in the Leisure Class was a major achievement, standing significantly above such precursors as those of Bagehot, Ritchie and others. Having started this research programme, however, he failed to move it forward (Rutherford, 1998). Cynthia Russett's (1976, p. 153) verdict was apposite and accurate:

If Veblen failed to develop an evolutionary methodology, he also failed to develop a comprehensive evolutionary theory to explain in detail how institutions evolve in the cultural environment and what sorts of interaction occur between economic activity and

\footnotetext{
12 Dobriansky's (1957) critique of Veblen failed to appreciate Darwinism. For example, Dobriansky (1957, p. 93) falsely upheld that natural selection implied both uniformity and finality, entirely contrary to its true meaning in terms of variety and process. Dobriansky grasped neither the philosophical significance of Darwinism nor its central place in Veblen's thought. Not uniquely, a critic thought he was attacking Veblen; but the critique carries more weight against the self-described 'Veblenians'. Daugert (1950) is superior and more accurate in its philosophical treatment of Veblen.
} 
institutional structures. Veblen was something of an intellectual butterfly, and he often lacked the patience to elaborate his ideas into a coherent system. But he teemed with fragmentary insights, and these can be pieced together to suggest the outlines of a Veblenian scheme of cultural evolution - what might be called a 'pre-theory' of cultural change.

We may conjecture on the reasons for Veblen's failure to develop a systematic evolutionary theory. In part they were probably due to difficulties in his personal and professional life (Jorgensen and Jorgensen, 1999). It is also evident that Veblen had no strong disposition towards the task of systematic theoretical development. But it also should be emphasized that Veblen was writing in an era when core Darwinian ideas were rarely understood, and they had not yet been fully systematized by other theorists. We had to wait for developments as late as the 1980s and 1990s, particularly in the philosophy of biology, for the clarification of key concepts such as selection, replication, and multiple-level evolution. Hence if we put Veblen's writings in their context and proper perspective, he emerges as a pioneer of a theoretical approach to the understanding of socio-economic evolution that is only beginning to be adequately formulated today.

A vital task for the social sciences is to come to grips with the nature and importance of Darwinism. Above all, Darwinism is a new philosophical system, signalling an unwavering commitment to causal explanation. It involves algorithmic explanations of process, rather than an exclusive focus on the properties of equilibria. Darwinism offers a vital meta-theoretical framework to understand all complex, evolving systems (Hodgson, 2004). Within this framework it is necessary to place additional theoretical explanations that are particular to the types of human and social phenomena at hand (Hodgson, 2001a). But without the overarching Darwinian framework we are either lost in a sea of detail or forced into a static or equilibrium analysis. Veblen was one of the first to apply this framework to social institutions and structures, and we must build up the positive parts of his Darwinian legacy. 


\section{References}

Argyrous, George and Sethi, Rajiv (1996) 'The Theory of Evolution and the Evolution of Theory: Veblen's Methodology in Contemporary Perspective', Cambridge Journal of Economics, 20(4), July, pp. 475-95.

Alexander, Samuel (1892) 'Natural Selection in Morals', International Journal of Ethics, 2(4), July, pp. 409-39.

Anderson, Karl L. (1933) 'The Unity of Veblen's Theoretical System', Quarterly Journal of Economics, 47(4), August, pp. 598-626.

Bagehot, Walter (1872) Physics and Politics, or, Thoughts on the Application of the Principles of 'Natural Selection' and 'Inheritance' to Political Society (London: Henry King). Reprinted in Norman St. John-Stevas (ed.) (1974) The Collected Works of Walter Bagehot (London: The Economist), vol. 7, pp. 15-144.

Bowler, Peter J. (1988) The Non-Darwinian Revolution: Reinterpreting a Historical Myth (Baltimore: Johns Hopkins University Press).

Brandon, Robert N. and Burian, Richard M. (eds) (1984) Genes, Organisms, Populations: Controversies Over the Units of Selection (Cambridge, MA: MIT Press).

Bunge, Mario A. (1959) Causality: The Place of the Causal Principle in Modern Science (Cambridge, MA: Harvard University Press).

Bunge, Mario A. (1980) The Mind-Body Problem: A Psychobiological Approach (Oxford: Pergamon).

Campbell, Donald T. (1965) 'Variation, Selection and Retention in Sociocultural Evolution', in Barringer, H. R., Blanksten, G. I. and Mack, R. W. (eds) (1965) Social Change in Developing Areas: A Reinterpretation of Evolutionary Theory (Cambridge, MA: Schenkman), pp. 19-49. Reprinted in General Systems, 14, 1969, pp. 69-85.

Commons, John R. (1924) Legal Foundations of Capitalism (New York: Macmillan).

Commons, John R. (1934) Institutional Economics - Its Place in Political Economy (New York: Macmillan).

Copeland, Morris A. (1936) 'Commons's Institutionalism in Relation to the Problem of Social Evolution and Economic Planning', Quarterly Journal of Economics, 50(2), February, pp. 333-46.

Darwin, Charles R. (1859) On the Origin of Species by Means of Natural Selection, or the Preservation of Favoured Races in the Struggle for Life, $1^{\text {st }}$ edn. (London: Murray).

Darwin, Charles R. (1871) The Descent of Man, and Selection in Relation to Sex, $1^{\text {st }}$ edn., 2 vols (London: Murray and New York: Hill).

Daugert, Stanley Matthew (1950) The Philosophy of Thorstein Veblen (New York: Columbia University Press).

Dawkins, Richard (1983) 'Universal Darwinism', in D. S. Bendall (ed.) (1983) Evolution from Molecules to Man (Cambridge: Cambridge University Press), pp. 403-25.

De Vries, Hugo (1901) Die mutationstheorie: Versuche und Beobachtungen über die Entstehung der Arten im Pflanzenreich, 2 vols. (Leipzig: Von Veit). 
Dennett, Daniel C. (1995) Darwin's Dangerous Idea: Evolution and the Meanings of Life (London: Allen Lane).

Desmond, Adrian and Moore, James R. (1991) Darwin (London: Michael Joseph).

Dobriansky, Lev E. (1957) Veblenism: A New Critique, with an introduction by James Burnham (Washington, DC: Public Affairs Press).

Dorfman, Joseph (1934) Thorstein Veblen and His America (New York: Viking Press).

Dugger, William M. (1984) 'Veblen and Kropotkin on Human Evolution', Journal of Economic Issues, 18(4), December, pp. 971-85.

Edgell, Stephen and Tilman, Rick (1989) 'The Intellectual Ancedents of Thorstein Veblen: A Reappraisal', Journal of Economic Issues, 23(4), December, pp. 1003-26.

Eldredge, Niles (1985) Unfinished Synthesis: Biological Hierarchies and Modern Evolutionary Thought (Oxford: Oxford University Press).

Harris, Abram L. (1934) 'Economic Evolution: Dialectical and Darwinian', Journal of Political Economy, 42(1), February, pp. 34-79.

Hayek, Friedrich A. (1988) The Fatal Conceit: The Errors of Socialism. The Collected Works of Friedrich August Hayek, Vol. I, ed. William W. Bartley III (London: Routledge).

Hill, Forest G. (1958) 'Veblen and Marx', in Dowd, Douglas F. (ed.) (1958) Thorstein Veblen: A Critical Appraisal (Ithica, NY: Cornell University Press), pp. 129-49.

Hindess, Barry (1989) Political Choice and Social Structure: An Analysis of Actors, Interests and Rationality (Aldershot: Edward Elgar).

Hodgson, Geoffrey M. (1998) 'The Approach of Institutional Economics', Journal of Economic Literature, 36(1), March, pp. 166-92.

Hodgson, Geoffrey M. (2001a) How Economics Forgot History: The Problem of Historical Specificity in Social Science (London and New York: Routledge).

Hodgson, Geoffrey M. (2001b) 'Darwin, Veblen and the Problem of Causality in Economics', History and Philosophy of the Life Sciences, 23, pp. 383-422.

Hodgson, Geoffrey M. (2002) 'Darwinism in Economics: From Analogy to Ontology', Journal of Evolutionary Economics, 12(2), June, pp. 259-81.

Hodgson, Geoffrey M. (2003) 'Darwinism and Institutional Economics', Journal of Economic Issues, 37(1), March, pp. 85-97.

Hodgson, Geoffrey M. (2004) The Evolution of Institutional Economics: Agency, Structure and Darwinism in American Institutionalism (London and New York: Routledge).

James, William (1880) 'Great Men, Great Thoughts, and the Environment', Atlantic Monthly, 46, pp. 441-59. Reprinted in James, William (1897) The Will to Believe and Other Essays in Popular Philosophy (New York and London: Longmans Green), pp. 216-54.

Jennings, Ann L. and Waller, William J. (1998) 'The Place of Biological Science in Veblen's Economics’, History of Political Economy, 30(2), Summer, pp. 189-217.

Joas, Hans (1996) The Creativity of Action (Chicago: University of Chicago Press).

Jorgensen, Elizabeth W. and Jorgensen, Henry I. (1999) Thorstein Veblen: Victorian Firebrand (Armonk, NY: M. E. Sharpe). 
Kaldor, Nicholas (1985) Economics Without Equilibrium (Cardiff: University College Cardiff Press).

Kidd, Benjamin (1894) Social Evolution (London and New York: Macmillan).

Langlois, Richard N. (ed.) (1986) Economics as a Process: Essays in the New Institutional Economics (Cambridge: Cambridge University Press).

Mises, Ludwig von (1949) Human Action: A Treatise on Economics (London: William Hodge).

Murphree, Idus L. (1959) 'Darwinism in Thorstein Veblen's Economics', Social Research, 26(2), October, pp. 311-24.

Myrdal, Gunnar (1939) Monetary Equilibrium, translated from the Swedish edition of 1931 and the German edition of 1933 (London: Hodge).

Myrdal, Gunnar (1957) Economic Theory and Underdeveloped Regions (London: Duckworth).

Ritchie, David G. (1896) 'Social Evolution', International Journal of Ethics, 6(2), pp. 165-81. Reprinted in Ritchie, David G. (1902) Studies in Political and Social Ethics (London and New York: Swan Sonnenschein and Macmillan).

Romanes, George John (1893) Darwin and After Darwin: An Exposition of the Darwinian Theory and a Discussion of Post-Darwinian Questions, vol. 1, 2nd edn. (London: Longmans, Green).

Ruse, Michael (1979) The Darwinian Revolution: Science Red in Tooth and Claw, $1^{\text {st }}$ edn. (Chicago: University of Chicago Press).

Russett, Cynthia Eagle (1976) Darwin in America: The Intellectual Response 1865-1912 (San Francisco: W. H. Freeman).

Rutherford, Malcolm H. (1998) 'Veblen's Evolutionary Programme: A Promise Unfulfilled', Cambridge Journal of Economics, 22(4), July, pp. 463-77.

Searle, John R. (1997) The Mystery of Consciousness (London: Granta Books).

Seckler, David (1975) Thorstein Veblen and the Institutionalists: A Study in the Social Philosophy of Economics (London: Macmillan).

Sober, Elliott and Wilson, David Sloan (1998) Unto Others: The Evolution and Psychology of Unselfish Behavior (Cambridge, MA: Harvard University Press).

Sperry, Roger W. (1991) 'In Defense of Mentalism and Emergent Interaction', Journal of Mind and Behavior, 12(2), pp. 221-46.

Tilman, Rick (1992) Thorstein Veblen and His Critics, 1891-1963: Conservative, Liberal, and Radical Perspectives (Princeton: Princeton University Press).

Tilman, Rick (1996) The Intellectual Legacy of Thorstein Veblen: Unresolved Issues (Westport, Connecticut: Greenwood Press).

Veblen, Thorstein B. (1898a) 'Why Is Economics Not an Evolutionary Science?', Quarterly Journal of Economics, 12(3), July, pp. 373-97. Reprinted in Veblen (1919).

Veblen, Thorstein B. (1898b) 'Why Is Economics Not an Evolutionary Science?', Quarterly Journal of Economics, 12(3), July, pp. 373-97. Reprinted in Veblen (1919). 
Veblen, Thorstein B. (1898c) 'The Instinct of Workmanship and the Irksomeness of Labor', American Journal of Sociology, 4(2), September, pp. 187-201. Reprinted in Veblen (1934).

Veblen, Thorstein B. (1899a) The Theory of the Leisure Class: An Economic Study in the Evolution of Institutions (New York: Macmillan).

Veblen, Thorstein B. (1899b) 'The Preconceptions of Economic Science: I', Quarterly Journal of Economics, 13(2), January, pp. 121-150. Reprinted in Veblen (1919).

Veblen, Thorstein B. (1900) 'The Preconceptions of Economic Science: III', Quarterly Journal of Economics, 14(2), February, pp. 240-69. Reprinted in Veblen (1919).

Veblen, Thorstein B. (1901a) 'Industrial and Pecuniary Employments', Publications of the American Economic Association, Series 3, 2(1), February, pp. 190-235. Reprinted in Veblen (1919).

Veblen, Thorstein B. (1901b) 'Gustav Schmoller's Economics', Quarterly Journal of Economics, 16(1), November, pp. 69-93. Reprinted in Veblen (1919).

Veblen, Thorstein B. (1903) Review of Pure Sociology: A Treatise Concerning the Origin and Spontaneous Development of Society by Lester Ward, Journal of Political Economy, 11(4), September, pp. 655-6. Reprinted in Veblen, Thorstein B. (1973) Essays, Reviews and Reports, ed. with an introduction by Joseph Dorfman (New York: Augustus Kelley).

Veblen, Thorstein B. (1904) The Theory of Business Enterprise (New York: Charles Scribners).

Veblen, Thorstein B. (1906) 'The Place of Science in Modern Civilisation', American Journal of Sociology, 11(1), March, pp. 585-609. Reprinted in Veblen (1919).

Veblen, Thorstein B. (1907) 'The Socialist Economics of Karl Marx and His Followers II: The Later Marxism', Quarterly Journal of Economics, 21(1), February, pp. 299-322. Reprinted in Veblen (1919).

Veblen, Thorstein B. (1908) 'Professor Clark's Economics', Quarterly Journal of Economics, 22(2), February, pp. 147-95. Reprinted in Veblen (1919).

Veblen, Thorstein B. (1909a) 'Fisher's Rate of Interest', Political Science Quarterly, 24(2), June, pp. 296-303. Reprinted in Veblen (1934).

Veblen, Thorstein B. (1909b) 'The Limitations of Marginal Utility', Journal of Political Economy, 17(9), November, pp. 620-36. Reprinted in Veblen (1919).

Veblen, Thorstein B. (1914) The Instinct of Workmanship, and the State of the Industrial Arts (New York: Macmillan).

Veblen, Thorstein B. (1915) Imperial Germany and the Industrial Revolution (New York: Macmillan).

Veblen, Thorstein B. (1919) The Place of Science in Modern Civilization and Other Essays (New York: Huebsch).

Veblen, Thorstein B. (1925) 'Economic Theory in the Calculable Future', American Economic Review (Papers and Proceedings), 15(1), March, pp. 48-55. Reprinted in Veblen (1934).

Veblen, Thorstein B. (1934) Essays on Our Changing Order, ed. Leon Ardzrooni (New York: The Viking Press). 
Young, Allyn A. (1928) 'Increasing Returns and Economic Progress', Economic Journal, 38(4), December, pp. 527-42.

Wolfe, Albert B. (1924) 'Functional Economics', in Tugwell, Rexford G. (ed.) (1924) The Trend of Economics (New York: Alfred Knopf), pp. 443-82. 